\title{
Soil carbon dioxide emission flux from organic and conventional farming in a long term experiment in Tuscany
}

\author{
Leonardo Verdi* \\ Department of Agriculture, Food, Environment and Forestry \\ (DAGRI) \\ University of Florence \\ Florence, Italy \\ leonardo.verdi@unifi.it \\ Margherita Santoni \\ Department of Agriculture, Food, Environment and Forestry (DAGRI) \\ University of Florence \\ Florence, Italy \\ margherita.santoni@unifi.it
}

\author{
Marco Napoli \\ Department of Agriculture, Food, Environment and Forestry (DAGRI) \\ University of Florence \\ Florence, Italy \\ marco.napoli@unifi.it
}

Anna Dalla Marta

Department of Agriculture, Food, Environment and Forestry (DAGRI) University of Florence

Florence, Italy

anna.dallamarta@unifi.it

Maria Teresa Ceccherini

Department of Agriculture, Food, Environment and Forestry (DAGRI)

University of Florence

Florence, Italy

mariateresa.ceccherini@unifi.it

\begin{abstract}
Soil microbial biomass represents a significant factor for the evaluation of soil fertility. In the present study we evaluated the development of the soil microbial biomass and soil $\mathrm{CO}_{2}$ emissions in two different agricultural systems: organic and conventional farming on sunflower. Organic farming ensures a higher development of soil microbial community than conventional farming (average 29.1 and $22.5 \mathrm{~kg}$ DNA harespectively). $\mathrm{CO}_{2}$ emissions proves that soil microbial community in organic farming is more active than conventional (1932.7 and $462.9 \mathrm{~kg} \mathrm{CO}_{2} \mathrm{ha}^{-1}$, respectively). This is also confirmed by the analysis of $\mathrm{qCO}_{2}$ where organic farming showed approximately three times higher $\mathrm{qCO}_{2}$ than conventional farming (66.3 and 20.5, respectively). However, crop yields highlighted as conventional farming is still more productive than organic farming. This is mainly due to the reduced amount of $\mathrm{N}$ that a mix of green manure (legumes and cereals) provide to the successive crop.
\end{abstract}

Keywords-Carbon dioxide, soil microbial biomass, organic farming, soil $\mathrm{DNA}, q \mathrm{CO}_{2}$

\section{INTRODUCTION}

The intensification of agricultural activities had led to an increase in crop yields. However, this result produced serious environmental problems and in this sense, one of the main issue is related to the maintenance of soil fertility at different levels [1]. If from one hand the availability of nutrients represents one of the main factor affecting crop production, from the other the maintenance of an active soil microbial community is fundamental for the conservation of soil fertility. Soil microbial biomass strongly affect the amount of soil organic matter and represents an important reservoir for plant nutrients [2, 3 4]. In addition, soil microbial community are carbon (C)-limited and their development is strictly connected to the amount and quality of organic-C into the soil. Several authors $[5,6]$ observed as more organic input are used the more the soil microbial community develop. Total $\mathrm{C}$ and nitrogen (N) soil content represents some of the most limiting factors for microbial community development. Nevertheless, [7] affirmed as the presence of easily degradable organic-C compounds mainly encourages a fast growth of soil microbial community. For these reasons, soil microbial community represents a sensitive indicator about the effect and changes produced by agricultural management practices on soil quality. Therefore, agricultural management activities play a key role on the development of soil microbial community and its planning requires specific considerations to create a suitable environment for soil biodiversity development. In this sense, the adoption of those management strategies that aim to reduce the use of external inputs, as mineral fertilizers, improve soil organic matter and minimum tillage are some of the most effective. For example, [8] observed as leaving crop residues on the soil surface enhance the increase of soluble organic compounds concentration into the soil and development of microbial community. Decomposition of biomass ensure the maintenance of certain organic matter levels into the soil. However, changes in land uses is negatively affecting the potential of $\mathrm{C}$ sequestration by the soils. In this sense, it has been observed as the land use changes are responsible to $25 \%$ of the total anthropogenic $\mathrm{CO}_{2}$ emissions [9]. As previously affirmed, soils can act as a sink of $\mathrm{C}$ through decomposition of biomass that stored atmospheric carbon dioxide $\left(\mathrm{CO}_{2}\right)$ via photosynthesis. Therefore, enhancing carbon sequestration into the soil results in an effective strategy to reduce $\mathrm{C}$ losses. However, soil may also act as a source of $\mathrm{C}$ during organic matter decomposition. This mainly occur as a consequence of alteration in soil quality and soil microbial community. [10], found that soil $\mathrm{CO}_{2}$ emissions represents the main cause of soil $\mathrm{C}$ losses. However, this parameter may be 
used as an early indicator for the estimation of soil organic $\mathrm{C}$ level in a short period $[11,12]$.

The evolution of agriculture produced different strategies to to hamper soil quality degradation and fertility losses while improving the sustainability of the process for the production of high yields with low impacts. Organic agriculture probably represents the most widespread strategy to reach these topics. Organic farming is constantly growing at an annual rate of $20 \%$ in the last decades [7] covering around 24 million of hectares at global scale. Nowadays, Italy is included in the ten countries with the largest area of organic agricultural land with approximately 1.9 million of hectares [13]. Organic farming shows a great potential to improve soil quality at physical, chemical and biological point of view enhancing aggregates formation, soil biodiversity and organic matter content $[1,14$, $15,16]$. Moreover, several authors found as organic farming represents an effective strategy to ensure high food quality standards [17, 18]. Nevertheless, due to the limited number of long-term experiments there are still sources of uncertainties on how sustainable is organic farming [1].

In the present study we evaluated the evolution of soil microbial community and its activity through the assessment of soil DNA yield and $\mathrm{CO}_{2}$ emissions fluxes in a long term experiment from organic and conventional farming in central Italy for a preliminary assessment of soil C-emissions, soil biodiversity and yields performances of the two cropping systems.

\section{MATERIALS AND METHODS}

\section{Site description}

Organic and conventional farming were carried out on Helianthus hannuus L. in order to assess environmental impacts and soil microbial dynamics from different agricultural management strategies. Field trials were located at the experimental farm of the University of Florence (Montepaldi,

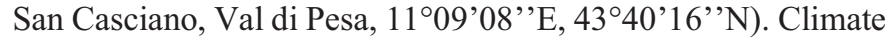
is typical from Mediterranean and Sub-Apennines area with mean annual precipitation of $770 \mathrm{~mm}$ concentrated in autumn and spring periods. From June to August drier conditions occur with highest temperatures and lowest precipitations [19]. Annual mean temperatures is $14.2^{\circ} \mathrm{C}$ with lower values on January and higher temperatures in August. For the studied period, Fig. 1 reports temperature (maximum and minimum) and precipitation trends. Soil texture of experimental site corresponds to a clay loam classification (Tab.1) and is composed by river Pesa fluvial deposits. Two trials, one for Organic (ORG) and one for Conventional (CON) farming of 1.3 hectares were sown to obtain a field plant density of 55.384 sunflower plant ha ${ }^{-1}$. Sunflower varieties used in the experiment were "Toscana" for ORG and "LG50.525" for CON. For each farming system, typical agricultural management strategies were carried out from preparation of the soil to harvest (Tab. 2). In particular, in ORG fertilization was performed through green manuring (tilled six days before sowing of sunflower) with a mix of oat (Avena sativa L.) and faba bean (Vicia faba L. var. minor). Fertilization in CON was performed using $150 \mathrm{~kg} \mathrm{ha}^{-1}$ of 20-10-10 N-P-K fertilizer (at sowing) and $150 \mathrm{~kg} \mathrm{ha}^{-1}$ of urea (at stem elongation phase). For testing the effectiveness of the two agricultural systems, flowers diameter, plant height, average number of seeds per plant, and yields $\left(\mathrm{kg} \mathrm{ha}^{-1}\right)$ were assessed at harvest time.

Table 1. Soil characteristics of Organic (ORG) and Conventional (CONV) trials

\begin{tabular}{|l|l|l|l|}
\hline & Unit & ORG & CON \\
\hline Sand & $\%$ & 20.2 & 21.0 \\
\hline Silt & $\%$ & 46.3 & 44.6 \\
\hline Clay & $\%$ & 32.9 & 33.8 \\
\hline pH & & 8.3 & 8.3 \\
\hline Gravel & $\%$ & 6.3 & 6.1 \\
\hline
\end{tabular}

\section{Soil carbon emissions, fluxes estimation and specific respiration of biomass $\left(q \mathrm{CO}_{2}\right)$}

For the monitoring of soil $\mathrm{CO}_{2}$ emissions, the closed static chamber technique was adopted [20]. Chambers were constructed as described by [21] and emissions were monitored using a portable gas analyser (Madur, XCGM 400) that uses a Nondispersive Infrared (NDIR) technology for $\mathrm{CO}_{2}( \pm 10 \mathrm{ppm})$ monitoring. Gas sampling was carried out inserting a needle, connected to the gas analyzer by a polytetrafluoroethylene tube, for one minute. Gas samplings were carried out immediately after chamber closing ( 0 ) and after one hour of gas accumulation ( $\mathrm{t} 1$ ) with the closed chamber. Difference between $\mathrm{T} 1$ and T0 represents gas concentration inside chambers. Gas concentrations (ppm), chamber dimensions (area and volume), closing time and molar weight of gas were used for gas fluxes calculation $\left(\mathrm{kg}-\mathrm{C} \mathrm{ha}{ }^{-1}\right)$. Gas samplings were carried out approximately two times per month all over the growing season of sunflower starting from $20^{\text {th }}$ April (cotyledons emergence) until $5^{\text {th }}$ September (physiological maturity) 2018. According to [21] measurements were performed during the mid-morning to find the moment of the day that more correspond to average daily temperatures. Interpolation methodology was used for the calculation of missing data from the days where measurements were not executed. The metabolic quotient $\left(\mathrm{qCO}_{2}\right)$ was calculated by the ratio of $\mathrm{CO}_{2}-\mathrm{C}$ to DNA yield ( $\mu \mathrm{g}$ DNA g ${ }^{-1}$ soil). This is in accordance to [11, 12, 22] affirming that DNA yield can be considered as an alternative to quantify microbial biomass.

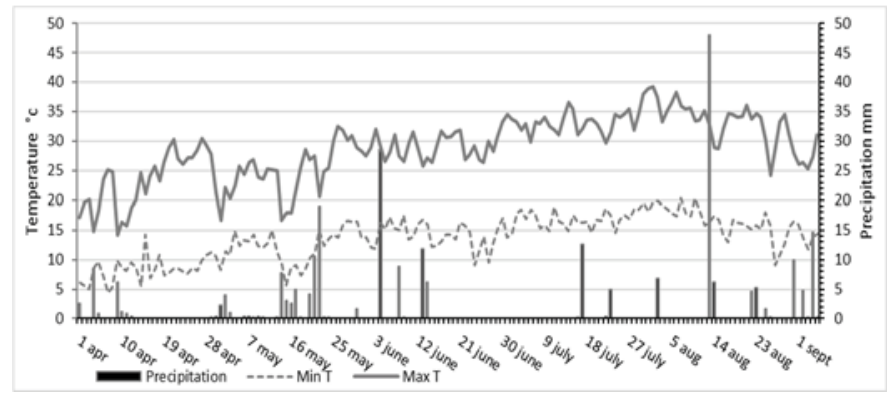

Figure 1. Daily maximum and minimum temperature, and precipitation during the experimental period

\section{Soil sampling for DNA extraction and soil microbial biomass}

Soil samples were collected with a core sampler $(2 \mathrm{~cm}$ diam.) from the top $15 \mathrm{~cm}$ in each plot. On every sampling occasion, ten cores were removed from each plot ( 5 in a row and 5 between 
rows), near the plant roots and transported from field to lab in sealed plastic bags on ice. Then the samples were sieved at 2 $\mathrm{mm}$ and stored at $-20^{\circ} \mathrm{C}$ until DNA extraction. The wholecommunity soil DNA was extracted by mechanical chemical cell lysis, from $0.5 \mathrm{~g}$ of soil and purified using the FastDNA spin Kit for Soil (MPBiomedicals) as described in [23]. Extracted DNA was quali-quantitatively characterized by agarose measurements (Picodrop), respectively; Picodrop-based quantification of double-stranded DNA (dsDNA) was performed as an alternative to estimate soil microbial biomass $[22,24]$. DNA samples were stored at $-20{ }^{\circ} \mathrm{C}$.

\section{Statistical analysis}

Data for the dependent variables $\left(\mathrm{CO}_{2}\right.$ emissions and soil microbial biomass) were subjected to univariate analysis of variances (ANOVA). The analysis was performed using $\mathrm{R}$ software and accessory packages (Fox, 2002; R Core Team, 2016; Sarkar, 2008; Venables \& Ripley, 2002). Tukey's posthoc test was applied as multiple means comparison techniques. Treatments effects from ANOVA analysis were considered significant at $\mathrm{p}<0.05$.

\section{RESULTS AND DISCUSSION}

\section{Soil $\mathrm{CO}_{2}$ emissions}

$\mathrm{CO}_{2}$ from aerobic and anaerobic processes, respiration of soil microflora, fauna and root respiration are included to the $\mathrm{CO}_{2}$ fluxes measured with the static chambers and can be considered as community $\mathrm{CO}_{2}$ production. As general trend, we observed a higher $\mathrm{CO}_{2}$ production in ORG, $1932.7 \mathrm{~kg} \mathrm{CO}_{2} \mathrm{ha}^{-1}$ $( \pm 216.9)$, during the whole monitoring period than $\mathrm{CON}, 462.9$ $\mathrm{kg} \mathrm{CO}_{2} \mathrm{ha}^{-1}( \pm 102.6)$. This is in accordance to the observations on DNA yields (Tab.2) that confirmed a higher development of soil microbial community in ORG than CON [1]. A higher development of soil microbial community in ORG may be favoured by the higher amount of organic matter provided to the soil through organic fertilization in ORG (green manuring) than $\mathrm{CON}$ that received a mineral fertilizer. This is corroborated by the findings of [25] that reported an annual average $C$ input of $1.20 \mathrm{Mg} \mathrm{ha}^{-1}$ in organic farming than $0.29 \mathrm{Mg} \mathrm{ha}^{-1}$ in conventional farming. Moreover, authors observed as the net soil organic C stock was roughly 0.090 and $0.55 \mathrm{Mg} \mathrm{ha}^{-1}$ for conventional and organic soil, respectively. From these results it was found a significantly higher soil organic $\mathrm{C}$ content in organic farming with an annual $\mathrm{C}$ gain of $0.45 \mathrm{Mg} \mathrm{ha}^{-1}$. The review produced by [26] shown an annual increase in soil organic $\mathrm{C}$ in organic soils of roughly $2.2 \%$. Differently, no significant changes were observed in conventional farming systems. However, observations from the whole monitoring period showed a similar trend of $\mathrm{CO}_{2}$ emissions between the two different farming systems (Fig. 2). Despite the reduction in $\mathrm{CO}_{2}$ production during the first week, probably due to the influence of tillage that temporary reduced microbial activity following soil mixing [27], we observed an increase in the emissions from the two treatments following crop growth during stem elongation phase that represent the most active period. After this phase, $\mathrm{CO}_{2}$ emissions decrease due to the increase of air temperature during summer (Fig. 1), decrease in soil moisture and the changes in plant physiology from vegetative to reproductive phase. However, direct soil $\mathrm{CO}_{2}$ emissions represents only one factor out of many others affecting environmental pressure of both conventional and organic farming. If from one hand conventional farming allows the adoption of synthetic inputs that produce significant impacts during the production process, transportation and use in field, from the other organic farming require a higher adoption of mechanicals (e.g. weed control) with consequentially intense use of fuels and high amount of manures that produces significant impacts during their management and use [28]. For these reasons, a wider assessment of both direct and indirect impact of conventional and organic farming, coupled with a specific evaluation of C-storage potential of each agricultural model, may provide useful information regarding the proper impact of different cropping systems.

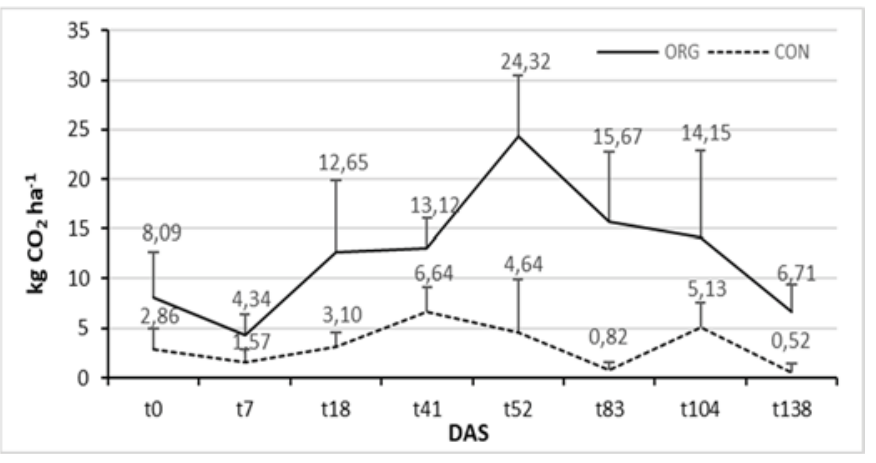

Fig. $2 \mathrm{CO}_{2}$ emissions trend during the monitoring period for organic (ORG) and conventional (CON) farming

\section{Soil microbial biomass}

Soil microbial community showed a similar development trend during the whole sunflower growing season between ORG and CON (Tab.2). However, in ORG we observed a higher amount of soil microbial community starting from the beginning of the growing season until sunflower harvest. The higher soil microbial growth was observed at 18 and this was confirmed by emissions observation. In particular, $\mathrm{t} 18$ correspond to the most significant increase in $\mathrm{CO}_{2}$ emissions from the two treatments. In addition, development of soil microbial community follows reproductive phase of sunflower that run approximately from $\mathrm{t} 7$ to $\mathrm{t} 52$ and decrease during grain ripening. However, at t138 we observed a significant increase in soil microbial community in the two treatments following a reduction in temperatures and a rainy period that provided ideal conditions for soil microbial community development. From the calculation of $\mathrm{qCO}_{2}$ we observed as the respiration activity is significantly higher $(\mathrm{p}<0.05)$ in ORG $(66.3)$ than in CON $(20.5)$ proving that the soil microbial biomass was more active in the organic trials (Fig. 3). 


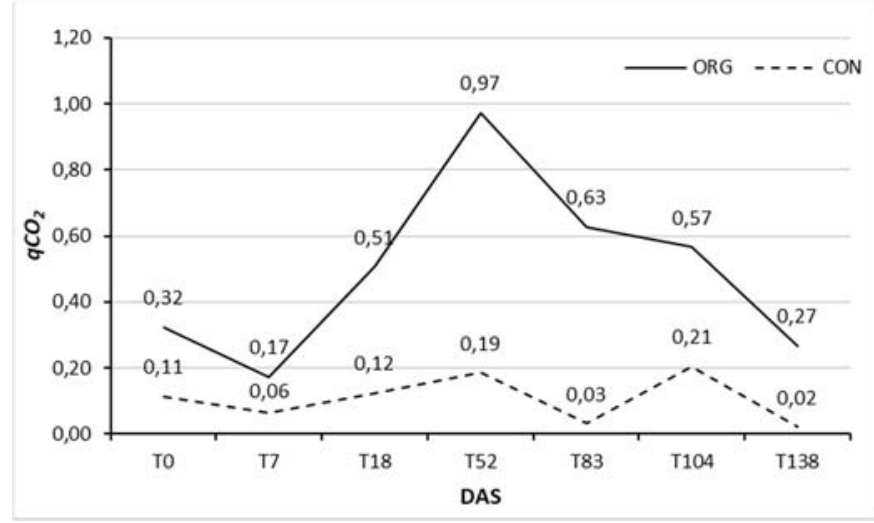

Fig. $3 \mathrm{qCO}_{2}$ trend during the monitoring period for organic (ORG) and conventional (CON) farming

In accordance to [1] a higher biodiversity at the soil level may make organic farming systems less dependent to external inputs. The size and the activity of soil microbial community represents an indicator about the quality of soils. In particular, the development of soil microbial community is directly related with organic $\mathrm{C}$ availability and its quality. The conservation of soil organic $\mathrm{C}$ pools contribute to maintenance of soil fertility. In this sense, the analysis of soil microbial community allows the evaluation of agricultural management strategies effectiveness. This is emphasized for organic farming models that rely on organic nutritional inputs [4].

Table 2. DNA yields at different growing season stages

\begin{tabular}{|c|c|c|c|c|}
\hline $\begin{array}{c}\text { Soil treatment } \\
\text { ORG }\end{array}$ & $\begin{array}{l}\text { Soil treatment } \\
\text { CON }\end{array}$ & Time & $\begin{array}{l}\text { ORG kg } \\
\text { DNA ha-1 }\end{array}$ & $\begin{array}{l}\text { CON kg } \\
\text { DNA ha-1 }\end{array}$ \\
\hline $\begin{array}{c}\text { Green } \\
\text { manuring + } \\
\text { Harrowing }\end{array}$ & Harrowing & to & $25( \pm 0.59)^{\mathrm{bcd}}$ & $17( \pm 0.51)^{\mathrm{de}}$ \\
\hline $\begin{array}{l}\text { Harrowing + } \\
\text { Seeding }\end{array}$ & $\begin{array}{c}\text { Harrowing }+ \\
\text { Seeding }+ \\
\text { Fertilization }+ \\
\text { Weeding } \\
\end{array}$ & $\mathrm{t} 7$ & $27( \pm 0.63)^{b c}$ & $19( \pm 0.41)^{\text {cde }}$ \\
\hline $\begin{array}{c}\text { Plant } \\
\text { emergence }\end{array}$ & Plant emergence & $\mathrm{t} 18$ & $38( \pm 0.70)^{\mathrm{a}}$ & $34( \pm 0.73)^{\mathrm{ab}}$ \\
\hline $\begin{array}{c}\text { Stem } \\
\text { elongation }+ \\
\text { Weed hoeing }\end{array}$ & $\begin{array}{c}\text { Stem elongation } \\
+ \text { Fertilization }+ \\
\text { Weed hoeing }\end{array}$ & $\mathrm{t} 52$ & $28( \pm 0.87)^{b c}$ & $29( \pm 0.48)^{\mathrm{abc}}$ \\
\hline Flowering & Flowering & t83 & $28( \pm 0.77)^{\text {bcd }}$ & $19( \pm 0.83)^{\mathrm{e}}$ \\
\hline $\begin{array}{l}\text { Development } \\
\text { of grains }\end{array}$ & $\begin{array}{l}\text { Development of } \\
\text { grains }\end{array}$ & $\mathrm{t} 104$ & $25( \pm 0.37)^{\mathrm{bcd}}$ & $14( \pm 0.34)^{\mathrm{f}}$ \\
\hline Ripening & Ripening & $\mathrm{t} 138$ & $33( \pm 0.72)^{a b}$ & $26( \pm 0.28)^{\text {bcd }}$ \\
\hline
\end{tabular}
significantly

\section{Sunflower phenology and yields}

Plant phenology and yields are mainly affected by climatic factors as precipitation, temperature and photoperiod. However, different agricultural management models might play an important role on the duration of different phenological phases and yields. From the analysis of plant phenology, we observed as sunflower shown higher performances in CON. This is highlighted for average flowers diameter that was 52\% lower in ORG $(6.26 \mathrm{~cm})$ than CON (13.09 cm). Average number of seeds per plant shown a similar trend and CON produced roughly $56 \%$ more seeds per plant (856.5) than ORG (371.9). However, differences between treatments were lower for plant height. In particular, plants in CON were roughly 20\% higher (average values) than ORG (144.4 and $117.1 \mathrm{~cm}$, respectively). These differences about plant phenology are probably due to the lower $\mathrm{N}$ input in ORG with the green manuring (approximately $40 \mathrm{~kg}$ $\mathrm{N} \mathrm{ha}^{-1}$ ) [29] compared to the chemical fertilization for CON (approximately $100 \mathrm{~kg} \mathrm{~N} \mathrm{ha}^{-1}$ ). Nevertheless, in both treatments, yields were lower compared to the average production for sunflower in Tuscany. This is mainly due to the dry season occurred in summer 2018 (Fig. 1) and the absence of an irrigation system. However, despite the higher soil microbial community observed in ORG, yields were higher in CON (210.4 $\mathrm{kg} \mathrm{ha}^{-1}$ ) than ORG (140.7 $\left.\mathrm{kg} \mathrm{ha}^{-1}\right)$. This is probably related to the reduced amount of $\mathrm{N}$ provided with green manuring in ORG than chemical fertilization of CON.

\section{CONCLUSION}

Direct $\mathrm{CO}_{2}$ emissions from agricultural soils are affected by a wide range of factors with different sources as the seasonal climate trend, soil characteristics (physical, chemical and biological), type of crops, agricultural management strategies, that are strictly related to each other. In this sense, organic farming ensures the improvement of soil microbial biomass. From the present study we observed as ORG soil result more suitable for soil microbial community development with approximately one-fourth more microbial biomass than CON. This is mainly due to the higher amount of organic matter provided to the soil with green manuring. In addition, we observed as soil microbial community in ORG results more active with significantly higher $\mathrm{CO}_{2}$ emissions and $\mathrm{qCO}_{2}$. Despite the improvement in soil quality and biological fertility, yields were higher in $\mathrm{CON}$ proving that further experimentation are needed for the definition of those organic agricultural management strategies that ensure an increase in crop yields.

\section{REFERENCES}

[1] P. Mäder, A. Fließbach, D. Dubois, L. Gunst, P. Fried, U. Niggli. Soil fertility and biodiversity in organic farming. Science 296: 1694- 1697, 2002

[2] D. S. Jenkinson, J. N. Ladd. Microbial biomass in soil: measurement and turnover. In Soil Biochemistry, eds E. A. Paul and J. N. Ladd, 5: 415471,1981

[3] T. Marumoto, J.P.E. Anderson, K.H. Domsch. Mineralization of nutrients from soil microbial biomass Soil Biol Biochem, 14: 469-475, 1982

[4] N. Gunapalaa, K.M.Scow. Dynamics of soil microbial biomass and activity in conventional and organic farming systems. Soil Biol Biochem, (30) 6: 805-816, 1998

[5] A. Fließbach, P. Mäder. Microbial biomass and size-density fractions differ between soils of organic and conventional agricultural systems. Soil Biol Biochem, 32: 757-768, 2000

[6] A. D. Peacock, M. D. Mullen, D. B. Ringelberg, D. D. Tyler, D. B. Hedrick, P. M. Gale, D. C. White. Soil microbial community responses to dairy manure or ammonium nitrate applications Soil Biol Biochem, 33: 1011-1019, 2001

[7] C. Tu, J. B. Ristaino, S. Hu. Soil microbial biomass and activity in organic tomato farming systems: effects of organic inputs and straw mulching. Soil Biol Biochem, 38: 247-255, 2006

[8] C. R. Alvarez, R. Alvarez, M. S. Grigera, R. S. Lavado. Associations between organic matter fractions and the active soil microbial biomass. Soil Biol Biochem, 30: 767-773, 1998 
[9] L. Denman, G. Brasseur, A. Chidthaisong, P. Ciais, P. M. Cox, R. E. Dickinson, D. Hauglustaine, C. Heinze, E. Holland, D. Jacob, U. Lohmann, S. Ramachandran, P. L. da Silva Dias, S. C. Wofsy, X. Zhang Couplings between changes in the climate system and biogeochemistry. In: S. Solomon, D. Qin, M. Manning, Z. Chen, M. Marquis, K. B. Averyt, M. Tignor, H. L. Miller, (Eds.), Climate Change 2007: The Physical Science Basis. Contribution of Working Group I to the Fourth Assessment Report of the Intergovernmental Panel on Climate Change. Cambridge University Press, Cambridge, United Kingdom/NewYork, NY,USA: 499-587, 2007

[10] B. Parkin, T. C. Kaspar. Temperature controls on diurnal carbon dioxide flux: Implications for estimating soil carbon loss. Soil Sci Soc Am J, 67: 1763-1772, 2003

[11] M. C. Fortin, P. Rochette, E. Pattey. Soil carbon dioxide fluxes from conventional and no-tillage small-grain cropping system. Soil Sci Soc Am J, 60: 1541-1547, 1996

[12] R. F. Grant. Changes in soil organic matter under different tillage and rotation: mathematical modeling in ecosys. Soil Sci Soc Am J, 61: 11591175,1997

[13] Eurostat, 2017. Organic farming statistics. https://ec.europa.eu/eurostat/statisticsexplained/index.php/Organic_farming_statistics\#Key_messages

[14] M. Pulleman, A. Jongmans, J. Marinissen, J. Bouma. Effects of organic versus conventional arable farming on soil structure and organic matter dynamics in a marine loam in the Netherlands, Soil Use Manage, 19: 157165,2003

[15] J.L. Doles, R.J. Zimmerman, J.C. Moore. Soil microarthropod community structure and dynamics in organic and conventionally managed apple orchards in Western Colorado, USA, Appl Soil Ecol, 18: 83-96, 2001F.

[16] Oehl, E. Sieverding, P. Mäder, D. Dubois, K. Ineichen, T. Boller, A. Wiemken. Impact of long-term conventional and organic farming on the diversity of arbuscular mycorrhizal fungi, Oecologia, 138: 574-583, 2004

[17] J.P. Reganold, J.D. Glover, P.K. Andrews, H.R. Hinman. Sustainability of three apple production systems, Nature, 410: 926-930, 2001

[18] J. Giles. Is organic food better for us, Nature, 428: 796-797, 2004
[19] S. Bedini, L. Avio, C. Sbrana, A. Turrini, P. Migliorni, C. Vazzana, M. Giovannetti. Mycorrhizal activity and diversity in a long-term organic Mediterranean agroecosystem. Biol Fert Soils, 49 (7): 781 - 790, 2013

[20] L. Verdi, P. J. Kuikman, S. Orlandini, M. Mancini, M. Napoli, A. Dalla Marta. Does the use of digestate to replace mineral fertilizers have less emissions of N2O and NH3? Agr Forest Meteorol 269-270: 112 - 118, 2019

[21] T.B. Parkin, R.T.Venterea. USDA-ARS GRACEnet project protocols, chapter 3. Chamber-Based Trace Gas Flux Measurements. (Replace Original Version of April 2003), 2010

[22] F. Fornasier, J. Asher, M.T. Ceccherini, E. Tomat, G. Pietramellara. A simplified rapid, low-cost and versatile DNA-based assessment of soil microbial biomass. Ecol indic, 45: 75-82, 2014

[23] J. Ascher, M.T. Ceccherini, O.L. Pantani, A. Agnelli, F. Borgognoni, G. Guerri, P. Nannipieri, G. Pietramellara. Sequential extraction and genetic fingerprinting of a forest soil metagenome. Appl Soil Ecol, 42 (2): 176 181,2009

[24] H. Marstorp, E. Witter. Extractable dsDNA and product formation as measures of microbial growth in soil upon substrate addition. Soil Biol Biochem, 31 (10): 1443-1453, 1999

[25] A. Gattinger, A. Muller, M. Haeni, C. Skinner, A. Fliessbach, N. Buchmann, P. Mader, M. Stolze, P. Smith, N. E. Scialabba, U. Niggli. Enhanced top soil carbon stocks under organic farming. Proceedings of the National Academy of Sciences, 109: 18226- 18231, 2012

[26] J. Leifeld, J. Fuhrer. Organic farming and soil carbon sequestration: What do we really know about the benefits? Ambio, 39:585-599, 2010

[27] R. P. Mathew, Y. Feng, L. Githinji, R. Ankumah, K. S. Balkcom. Impact of No-tillage and conventional tillage on soil microbial communities. Applied Environ Soil Sci., 1-10, 2012

[28] K. Meisterling, C. Samaras, V. Schweizer. Decisions to reduce greenhouse gases from agriculture and product transport: LCA case study of organic and conventional wheat, J Clean Prod, 17(2): 222-230, 2009

[29] A. Tarui, A. Matsumura, S. Asakura, K. Yamawaki, R. Hattori, H. Daimon. Evaluation of mixed cropping of oat and hairy vetch as green manure for succeeding corn production. Plant Prot Sci, 16: 383-392, 2013 